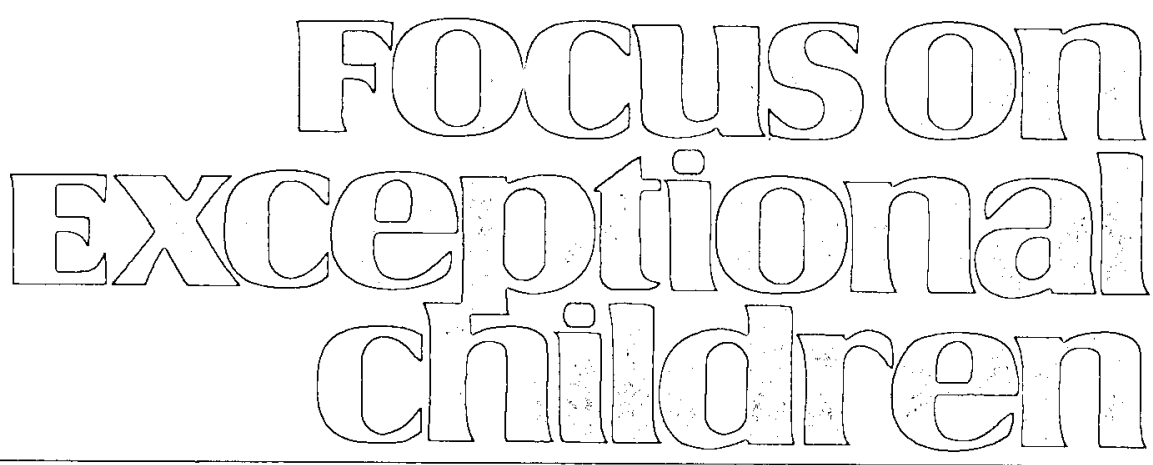

\title{
Reflections on the 25th Anniversary of the U.S. Supreme Court's Decision in Board of Education v. Rowley
}

\author{
Mitchell L. Yell, Antonis Katsiyannis, and Michael Hazelkorn
}

June 22, 2007, was the 25th anniversary of the U.S. Supreme Court's decision in Board of Education of the Hendrick Hudson Central School District v. Rowleyl (hereafter Rowley; 1982). In Rowley, the Supreme Court interpreted congressional intent in requiring that public schools provide a free appropriate public education (FAPE) to students with disabilities under the Individuals with Disabilities Education Act (IDEA). This rulingwhich is arguably the most important special education decision by the high court-has had a profound effect on the education of students with disabilities.

In this article we reflect on the importance of this decision and discuss how changes in IDEA in the 1997 and 2004 reauthorizations have changed the definition of a FAPE. First, we briefly review passage of the Education for All Handicapped Children Act ${ }^{2}$ (EAHCA) in 1975. Second, we examine the facts of the Rowley case and the Supreme Court's ruling. Third, we look at some court cases following Rowley, which interpreted the meaning of the Supreme Court's ruling. Fourth, we consider the effects of IDEA 1997 and 2004 on the meaning of FAPE. Finally, we discuss principles that school districts should follow when developing individualized education programs (IEPs) that provide a FAPE for students with disabilities.

\section{THE EDUCATION FOR ALL HANDICAPPED CHILDREN ACT OF 1975}

Prior to 1975, the access of students with disabilities to educational opportunities was limited in two major ways (Katsiyannis, Yell, \& Bradley, 2001; Yell, Drasgow, Bradley, \& Justesen, 2004):

1. Many students were excluded completely from public schools. In fact, congressional findings in 1974 indicated that more than 1.75 million students with disabilities did not receive educational services.

Mitchell L. Yell is with the University of South Carolina; Antonis Katsiyannis with Clemson University; and Michael Hazelkorn with the University of West Georgia.

'For a fascinating account of the Rowley case, see A Case about Amy by R. C. Smith (ISBN 1-56639-412-0), published by Temple University Press, Philadelphia. When writing the book, Smith had access to the extensive files kept by the Rowleys and the Hendrick Hudson Central School District. In addition, he conducted numerous interviews with the Rowley family and others on both sides of the case. Much of the background information on the Rowley case described in this article is from this excellent book.

${ }^{2}$ The title of the Education for All Handicapped Children Act was changed to the Individuals with Disabilities Education Act in the reauthorization of 1990. 
2. More than 3 million students with disabilities who were admitted to school did not receive an education that was appropriate to their needs.

To address these problems, on November 29, 1975, President Gerald Ford signed into law the most significant increase in the role of the federal government in special education to date-EAHCA.

The EAHCA combined an educational bill of rights with the promise of federal financial incentives. The Act contained provisions requiring that states, to receive federal funding, had to develop laws and regulations ensuring that all eligible students with disabilities would receive a special education. The EAHCA required participating states to provide a free appropriate public education (FAPE) for all qualified students with disabilities between the ages of 3 and 18 by September 1, 1978, and for all students up to age 21 by September 1, 1980. Further, the EAHCA mandated that eligible students with disabilities had the right to a FAPE.

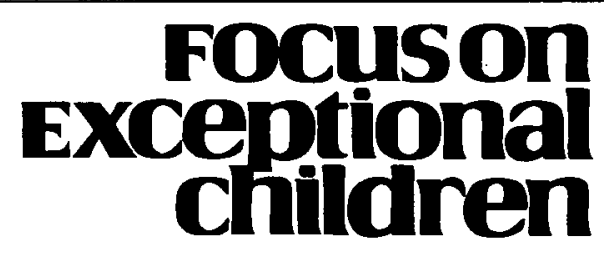

ISSN 0015-511X FOCUS ON EXCEPTIONAL CHILDREN (USPS 203-360) is published monthly except June, July, and August as a service to teachers, special educators, curriculum specialists, administrators, and those concerned with the special education of exceptional children. This publication is annotated and indexed by the ERIC Clearinghouse on Handicapped and Gifted Children for publication in the monthly Current Index to Journals in Education (CIJE) and the quarterly index, Exceptional Children Education Resources (ECER). The full text of Focus on Exceptional Children is also available in the electronic versions of the Education Index. It is also available in microfilm from Serials Acquisitions, National Archive Publishing Company, P.O. Box 998, Ann Arbor, MI 48106-0998. Subscription rates: individual, $\$ 42$ per year; institutions, $\$ 56$ per year. Copyright $\odot$ 2007, Love Publishing Company. All rights reserved. Reproduction in whole or part without written permission is prohibited. Printed in the United States of America. Periodical postage is paid at Denver, Colorado. POSTMASTER: Send address changes to:

Love Publishing Company Executive and Editorial Office P.O. Box 22353

Denver, Colorado 80222

Telephone (303) 221-7333

\section{EDITORIAL BOARD}

Lisa Dieker

University of Central Florida

Marleen Pugach

University of Wisconsin-Milwaukee
Paula Maccini University of Maryland
Watterson Editor
Stanley F. Love Publisher

\section{FAPE}

The EAHCA defined a FAPE as special education and related services that
(A) are provided at public expense, under public supervision and direction, and without charge,
(B) meet standards of the State educational agency,
(C) include an appropriate preschool, elementary, or sec- ondary school education in the state involved, and
(D) are provided in conformity with the individualized edu- cation program. (IDEA, 20 U.S.C. \& 1401(a)(18))

The key to providing a FAPE was for school personnel to develop and implement a program based on a full and individualized assessment of a student that would consist of specially designed instruction tailored to meet the unique needs of a child with a disability (IDEA, 20 U.S.C. $\$ 1401$ (a)(16)). What would constitute an appropriate education, therefore, would vary from student to student.

To ensure that each student covered by the EAHCA would receive an individualized FAPE, Congress required that an individualized education program (IEP) be developed for all students in special education. The special education and related services for a student would be delineated in, and provided in conformity with, the student's IEP. Thus, the IEP was the blueprint of a student's FAPE.

When writing the original EAHCA, however, Congress did not define a FAPE in a manner that listed the actual substantive educational requirements. Rather, Congress defined a FAPE primarily in accordance with the procedures necessary to ensure that parents and school personnel would collaborate to develop a student's program of special education. Congress believed that requiring IEPs to be developed in this manner would ensure a FAPE. Thus, the definition of a FAPE in the original EAHCA was primarily procedural rather than substantive.

In the years following passage of the EAHCA, the question of what exactly constituted a FAPE generated much discussion, controversy, and debate. Although the free education and the public education parts of a FAPE were rarely disputed, what an appropriate education would be for any given child was the frequent subject of due process heárings and court cases (Wenkart, 2000). The most important case regarding FAPE was heard by the U.S. Supreme Court on March 22, 1982-the Rowley case.

\section{BOARD OF EDUCATION OF THE HENDRICK HUDSON CENTRAL SCHOOL DISTRICT V. ROWLEY (1982)}

Nancy and Clifford Rowley had both become deaf as the result of childhood diseases. They had a son, John, who had normal hearing, and a daughter, Amy, who also was born 
with normal hearing. Amy, like her parents, lost her hearing to a childhood disease. Amy's parents brought her up using manually coded English, lipreading, and amplification of her residual hearing. Both of the Rowley's children were extremely bright; Amy's IQ was above 120 (Smith, 1996).

A little more than a year before their daughter was to enter kindergarten, Nancy Rowley met with the principal of the Furnace Woods Elementary School in the Hendrick Hudson Central School District, Montrose, New York. Nancy, a certified teacher of deaf students, wanted Amy to attend Furnace Woods and also to be mainstreamed into general education with a sign language interpreter in the classroom.

The other option that had been discussed was to send Amy to the New York School for the Deaf. Although the School for the Deaf had many services available, including sign language interpreters, a committee for the education of students with disabilities in the Hendrick Hudson School District ruled out this option because it did not believe the school could meet Amy's academic needs. During this time, the state of New York was still developing regulations to implement the EAHCA; nevertheless, the concept of mainstreaming was not new either to the principal or the committee members.

The meeting between Nancy Rowley and the Furnace Woods principal, Joe Zavarella, went well, although Ms. Rowley noted that the principal believed the school district might resist providing an interpreter. Mr. Zavarella later wrote to Ms. Rowley, explaining that a number of approaches would be used to make Amy's experiences at Furnace Woods successful, including a trial period with an FM wireless hearing aid system and a sign language interpreter. A number of teachers and staff members also had agreed to take a sign language course to assist them in working with Amy. After the trial period was over, they would develop an IEP for Amy.

Before the IEP meeting was held, the Rowleys filed a complaint under Section 504 of the Rehabilitation Act of 1973. The complaint, filed with the Civil Rights Division of the U.S. Department of Health, Education and Welfare, alleged that the school district had violated Amy's civil rights because it had failed to provide a sign language interpreter. The Rowleys were represented by the National Center for Law and Education. The complaint convinced many officials in the school district that they were being targeted in a national effort to create a test case regarding students with disabilities (Smith, 1996). Later that year, the Office of Civil Rights ruled that the school district was in compliance with Section 504 and dismissed the complaint.

In January 1978, an IEP meeting was held, and shortly thereafter a sign-language interpreter was assigned to Amy's class. After the 9-day trial period, the sign language interpreter reported that Amy usually resisted the assistance, and that because Amy was doing quite well, she did not need a sign language interpreter at that time. He did note, however, that Amy may need an interpreter in the future when academic work would become more difficult and large-group discussions would be used more frequently.

School officials decided that an interpreter would not be provided for Amy. A few weeks later, the team reconvened to write Amy's IEP for first grade. The school offered to provide Amy with the services of a speech and auditory specialist twice a week, as well as tutorial assistance from a teacher certified to teach deaf students. The Rowleys refused to sign the IEP. They hired a lawyer, Michael Chatoff, who also was deaf. He believed that the best way to proceed would be to request a due process hearing under the EAHCA.

In December 1978, a due process hearing was held. A month later, the hearing officer found that Furnace Woods Elementary School was providing Amy with an appropriate education. An appeal of the hearing was heard by the New York Commissioner of Education. In a brief decision issued in April 1979, the Commissioner upheld the due process hearing officer's finding. The Rowleys filed suit against the Hendrick Hudson Central School District in the United States District Court for the Southern District of New York.

\section{The Federal District Court Decision}

In September and October 1979, the suit was heard by Judge Vincent Broderick of the U.S. District Court (Amy Rowley v. Hendrick Hudson Central School District, 1979). In December, Judge Broderick issued a two-page opinion reversing the finding of the Commissioner of Education and ordering the Hendrick Hudson School District to provide Amy with a sign language interpreter. In his opinion, the judge wrote that the district had not provided Amy with an appropriate education, which he defined as an education that would result in "each handicapped child being given an opportunity to achieve his full potential commensurate with the opportunity provided other children" (p. 534).

The judge further wrote that such a standard would require that the potential of a child with disabilities be measured and compared to his or her performance, and that the resulting difference be compared to the difference experienced by nondisabled children. Judge Broderick also concluded that, because of her disability, Amy was not learning as much or performing as well as she could have if she did not have a disability, and that a sign language interpreter would help to alleviate the difference between her potential and what she actually was learning. The school district appealed the district court's decision to the United States Court of Appeals for the Second Circuit.

\section{The Court of Appeals Decision}

On May 1980, the Rowley case went before the threejudge panel of the U.S. Court of Appeals. In July of that 
year, the Court of Appeals issued its ruling, a 2-to-1 decision affirming the decision of the district court. In a short threepage opinion, the court found that without a sign language interpreter, Amy did not have the same opportunity that her classmates had. The court did not discuss the meaning of the word "appropriate" in the EAHCA; rather, it noted the narrow scope of the ruling. The dissenting judge, however, wrote a 19-page opinion strongly defending the actions of the school district. Moreover, the dissenting judge disagreed with the district court's definition of "appropriate."

In December 1980, the school district appealed the circuit court's ruling to the United States Supreme Court. In November 1982, the Supreme Court granted certiorari. In March 1982, arguments were held before the Supreme Court.

\section{The Supreme Court Decision}

When the Supreme Court announced that it would review the Rowley case, many advocates for students with disabilities were upset and worried, although they continued to support the Rowleys (Smith, 1996). There were several reasons for the dislike of this specific case being the first special education case to be heard by the U.S. Supreme Court:

1. Because Amy was not a typical child in special education program (she was very bright and was doing well in school), the facts were far less compelling than if she were not bright and failing badly in school.

2. The school district was in fact providing Amy with an array of services, unlike many children in special education programs who received minimal or no services whatsoever.

3. The timing seemed bad because the court had become more conservative, and advocacy groups worried that the high court may use the case to raze the EAHCA and possibly declare the law unconstitutional.

The Rowleys' attorney, Michael Chatoff, who had been with them since the original due process hearing, was to argue their case before the Supreme Court. Interestingly, this was the first time that a deaf lawyer would speak in front of the Supreme Court, the first occasion that real-time translation equipment would be used in the high court, and only the second time that Chatoff had ever argued a case in any court.

In the oral arguments, the school district's attorney began by emphasizing the special services the district had provided to Amy (i.e., having the staff take a sign language course, installing the TTY communication device in the principal's office, positioning Amy where she could make eye contact with everyone in the classroom, supplying Amy with an FM wireless hearing aid, having a teacher of the deaf work with Amy for an hour each day, and providing Amy with speech therapy services three times a week) and argued that Amy, given her high IQ, was performing exactly as she was expected to achieve.

He also argued that the school district had built "bridges of meaning" to Amy, and the courts had destroyed these bridges and substituted their own ideas of appropriate programming based on an inaccurate reading of the EAHCA (Smith, 1996, p. 141). The attorney further asserted that the full potential standard announced by the district court was simply unworkable.

The Rowleys' attorney argued that the case was not about Amy reaching her full potential. Rather, the case was about the school district's failing to develop an educational program that met Amy's unique needs and provided her with equal educational opportunity.

The Supreme Court's decision was announced on June 29, 1982. The majority opinion, written by Justice Rehnquist, ruled that the Hendrick Hudson School District had provided an appropriate education to Amy. Justice Rehnquist's opinion, joined by Chief Justice Burger and Justices Powell, O'Conner, and Stevens, held that Congress had intended that to deliver a FAPE, school districts had to provide personalized instruction with sufficient support services to permit a child with a disability to benefit educationally, which had been satisfied in this case.

Justice White wrote a dissenting opinion, joined by Justices Brennan and Marshall, in which he concluded that in the EAHCA, Congress had intended that, to satisfy the FAPE requirement, a school had to provide equal educational opportunity to a student with a disability. Justice Blackmun filed a concurring opinion, in which he also concluded that Congress intended that schools provide equal educational opportunity; however, he determined that the Hendrick Hudson School District had met this standard.

The majority noted that the EAHCA required that special education services be provided at public expense, meet state standards, and comport with the student's IEP. If individualized instruction allowed the child to benefit from educational services and was provided in conformity with the other requirements of the law, the student was receiving a FAPE. The court noted that any substantive standard prescribing the level of education to be accorded students with disabilities was absent from the language of IDEA, and that Congress had sought primarily to make public education available to children with disabilities. Thus, according to the court, "The intent of the (EAHCA) was more to open the doors of public education to handicapped children on appropriate terms than to guarantee any particular level of education once inside" (Rowley, 1982, p. 183).

The Supreme Court developed a two-part test for courts to use in determining whether a school has met its obligations under IDEA to provide a FAPE: 
First, has the [school] complied with the procedures of the Act? And second, is the individualized education program developed through the Act's procedures reasonably calculated to enable the child to receive educational benefits? (Rowley, 1982, pp. 206-207).

If these obligations were met, a school had complied with FAPE's requirements. The court cautioned the lower courts, however, that it was not establishing any one test for determining the adequacy of educational benefits.

Applying the two-part test to the facts of the Rowley case, the Supreme Court found that the school district had complied with the procedures of IDEA and Amy had received an appropriate education because she was performing better than many children in her class and was advancing easily from grade to grade. In a footnote, the high court noted that the decision was a narrow one, and that it should not be read too broadly. The Court stated that the ruling should not be interpreted to mean that every student with a disability who was advancing from grade to grade in a regular school was automatically receiving a FAPE. Rather, the FAPE standard could be arrived at only through a multifactorial evaluation conducted on a case-by-case basis. The high court also noted that in this case the sign language interpreter was not required to provide a FAPE to Amy Rowley. The decisions of the district court and circuit court were reversed.

For the past 25 years, the Rowley decision undoubtedly has been the most important and influential case in special education law (Johnson, 2003). The Rowley standard-that school districts had to provide special education programs that conferred educational benefit, and that what constituted a FAPE had to be determined by IEP teams on a case-bycase basis-has guided school districts' thinking about these issues. Still, the Rowley standard has evolved in subsequent court cases. We next examine some of these post-Rowley decisions.

\section{POST-ROWLEY COURT DECISIONS}

Because Congress did not specify any specific level of educational benefit that must be provided to special education students in the EAHCA, and the Supreme Court in Rowley did not establish a single test for determining FAPE, other courts have often been called on to interpret what constitutes a FAPE for students with disabilities and whether these students have received educational benefits from the special education provided to them. Of course, these courts have relied on the Rowley decision in ruling on such cases because it is the standard against which special education services are measured (Johnson, 2003).

These decisions have followed the Rowley standard by ruling that the EAHCA does not require that school-based teams develop IEPs that provide students with the best possible education, nor does it require that students receive services that enable them to reach their maximum potential. Nonetheless, some courts have expanded on what has sometimes been referred to as the Rowley "some educational benefit" standard, although it still remains essentially intact (Johnson, 2003, p. 1).

\section{The Meaningful Benefit Standard}

Some courts have ruled that to provide a FAPE, schools must develop special education programs that enable their students with disabilities to achieve meaningful benefit, and that the student must make some tangible progress. For example, the U.S. Court of Appeals for the Third Circuit, in Polk v. Central Susquehana Intermediate Unit 16 (1988), held that the EAHCA requires that IEPs be developed that confer more than trivial or de minimus educational benefit but lead to meaningful benefit and significant learning.

In the Polk decision, the court noted that because Rowley involved a student who did very well in the general education class, the high court was able to avoid the substantive second principle of the Rowley test (i.e., whether the IEP was reasonably calculated to provide educational benefit) and concentrate on the procedural principle. Thus, because Amy Rowley was an excellent student, the court had only to examine the procedures the district followed, and the court found that clearly she must have been receiving an appropriate education because she was one of the top students in her class and had been advanced to the next grade. In the case before the third circuit court, however, the substantive question of how much benefit was required to meet the "meaningful" standard in educating the plaintiff, Christopher Polk, was inescapable.

Christopher Polk was a 14-year-old with severe mental and physical disabilities. The severity of his disabilities necessitated physical therapy, but the school's IEP provided only the consultative services of a physical therapist. Christopher's parents brought action under the EAHCA, claiming that the school had failed to provide an appropriate education for their son. A federal district court held for the school district, finding that the Rowley standard held that the conferral of any degree of educational benefit, no matter how small, could qualify as an appropriate education. The circuit court reversed the district court, declaring that

\footnotetext{
Congress did not write a blank check, neither did it anticipate that states would engage in the idle gesture of providing special education designed to confer only trivial benefit.... Congress intended to afford children with special needs an education that would confer meaningful benefit. (Polk, 1988, p. 184)
}

The court also stated that the type of education that constitutes a meaningful education can be determined only in 
light of a student's potential. Courts in Board of Education of East Windsor Regional School District v. Diamond (1986), Doe v. Smith (1988), and Hall v. Vance County Board of Education (1985) all reached a similar conclusion.

In Cypress-Fairbanks Independent School District $v$. Michael F. (1997), the U.S. Court of Appeals for the Fifth Circuit also relied on earlier rulings of other circuits (see Board of Education of East Windsor Regional School District v. Diamond, 1986; Hall v. Vance County Board of Education, 1985) in deciding that to confer a FAPE, a student's educational benefits cannot be a mere modicum or de minimis, but must be "likely to produce progress, not regression or trivial educational advancement." In short, the educational benefit that an IEP is designed to achieve must be "meaningful" (Cypress, 1997, p. 248). The court adopted the district court's following four indicators to analyze whether an IEP had been reasonably calculated to provide a meaningful benefit under IDEA:

1. The program must be individualized on the basis of the student's assessment and performance.

2. The program must be administered in the least restrictive environment.

3. The services must be provided in a coordinated and collaborative manner by the key stakeholders.

4. Positive academic and nonacademic benefits must be demonstrated.

Courts also have ruled that to confer a meaningful education, some students' special education programs should include more than traditional academic skills and develop students' basic self-help and social skills such as toilet training, dressing, feeding, and communication (see Battle $v$. Commonwealth of Pennsylvania, 1980; Polk v. Central Susquehanna Intermediate Unit 16, 1988; and Timothy W. v. Rochester School District, 1989). In Polk, the Third Circuit decided that because a child "may never achieve the goals set in a traditional classroom does not undermine the fact that his brand of education (training in basic life skills) is an essential part of [the Act's] mandate" (p. 183). The First Circuit in Timothy $W$. concluded that education need not be measured by acquiring traditional academic skills; rather, education was to be broadly defined to include a child's social, emotional, medical, or educational problems.

These post-Rowley decisions have shown that courts will adhere to the controlling authority of Rowley and will apply the Rowley standard when ruling on issues of FAPE. These rulings also show, however, that many courts have moved beyond the "some educational benefit" standard and have required that students receive meaningful benefit or make meaningful progress (see Burlington School Committee v. Massachusetts Department of Education, 1985; Board of
Education of East Windsor Regional School District v. Diamond, 1986; Polk v. Central Susquehanna Intermediate Unit 16, 1988; Roland M. v. Concord School Committee, 1990; Chris C. v. Gwinnett County School District, 1991; J. C. v. Regional School District, 1996; Hall v. Vance County Board of Education, 1985; Cypress-Fairbanks Independent School District v. Michael F., 1997; Ridgewood Board of Education v. N. E., 1999; Ross v. Framington School Committee, 1999; Nein v. Greater Clark County School Corporation, 1999). Although these decisions did not require a school to deliver the best possible education, or to maximize students' potential, the rulings did stress the importance of examining a student's potential and ability when determining whether he or she (a) progressed and (b) received demonstrable educational benefit (Johnson, 2003).

\section{IEPs and FAPE}

Courts also have addressed the question of how to determine whether a school district has provided a FAPE. Their answers have often been to examine a student's IEP. The U.S. Court of Appeals for the Fourth Circuit, in Hall $v$. Vance County Board of Education (1985), held that the Rowley decision required courts to examine IEPs to determine what substantive standards meet the second principle of the Rowley test. In addition, the court cited Rowley as stating that this could be accomplished only on a case-bycase basis.

The appeals court affirmed the district court's ruling that because the plaintiff, who had a learning disability, had made no educational progress in the public school, and because the IEP was inadequate, the school district had to reimburse the parents for private school tuition. The court noted that Congress did not intend schools to offer educational programs that produce only trivial academic advancement.

In Carter v. Florence County School District Four (1991), the U.S. Court of Appeals for the Fourth Circuit affirmed a district court's ruling that the school district's IEP had failed to satisfy the FAPE requirement of IDEA. The IEP, which contained annual reading goals of 4-months' growth over a school year, did not, according to the district court and the circuit court, represent meaningful growth, even if the goals were achieved. Thus, the school district's IEP was ruled invalid. Later, the case was heard by the U.S. Supreme Court on a different issue.

In J. C. v. Central Regional School District (1996), the U.S. Court of Appeals for the Third Circuit ruled that school districts must provide more than a de minimus or trivial education, and that districts are responsible for adequacy of the IEP. In this case, the IEP developed for a student with severe disabilities failed to address important educational needs. Furthermore, the student had made little progress in the current program and had actually regressed in some areas. 
The U.S. Court of Appeals for the Fifth Circuit, in Houston Independent School District v. Bobby R. (2000), ruled that the student with learning disabilities received an appropriate education because the school had data showing that the student had received academic and nonacademic benefit. Moreover, the circuit adopted the four-part test used by the circuit court in the Cypress-Fairbanks case. To determine if academic benefits had been demonstrated, the court examined the school's testing data. Finding that Bobby's test scores had shown a good rate of improvement, even though it was not commensurate with his peers in general education, the court held that the student's progress should be measured in relation to his own degree of improvement rather than in relation to his nondisabled peers. The court ruled, therefore, that Bobby's IEP was reasonably calculated to provide him with meaningful educational benefit, thus meeting the requirements of IDEA.

In Pace v. Bogalusa City School Board (2003), the U.S. Court of Appeals for the Fifth Circuit looked to Rowley and its earlier rulings (Cypress-Fairbanks, 1997; Houston Independent School District v. Bobby R., 2000) for guidance in deciding whether a student's IEP was reasonably calculated to enable him to receive educational benefits. Relying on the language that it had used in Cypress-Fairbanks, the court stated that a FAPE as described in an IEP

need not be the best possible one, nor one that will maximize the child's educational potential; rather, it need only be an education that is specifically designed to meet the child's unique needs, supported by services that will permit him "to benefit" from the instruction. (p. 619)

The court used the four factors that it had adopted in Cypress to determine whether the IEP was reasonably calculated to provide him with an educational benefit. Objective evidence, in the form of test scores, indicated that the student had made academic gains. In addition, he met the goals to improve his flexibility, mobility, and trunk strength. The court concluded that the student had "received both positive academic and non-academic benefits from his educational program" (p. 620).

These decisions show that courts often will examine a school district's IEP when determining whether the district provided a FAPE (Osborne \& Russo, 2006). The IEP is the blueprint of a student's FAPE, and all special education teachers must understand its purpose and function (Huefner, 2000; Yell, 2006).

The importance of an IEP to help courts determine whether a FAPE was provided to a student was underscored by the New Jersey Supreme Court in Lascari v. Board of Education (1989). In this case, the New Jersey high court determined that the student had not received a FAPE because the IEP was done so poorly. Specifically, the court found that the current levels of performance were not complete, the goals and objectives were so vague as to be meaningless, and the IEP contained no method for measuring student progress toward the goals. For these reasons, the court found that the IEP was inappropriate, resulting in the denial of FAPE (Huefner, 2000). These decisions indicate that courts often use the IEP as the primary mechanism for determining whether a FAPE is being provided (Huefner, 2000; Yell, 2006).

\section{FAPE AND THE IDEA REAUTHORIZATIONS OF 1997 AND 2004}

\section{IDEA Amendments of 1997}

When the EAHCA was passed in 1975, Congress intended that the law open the doors of public education for students with disabilities. Thus, the emphasis of the original law was on access to educational programs rather than any level of educational opportunity (Eyer, 1998; Huefner, 2000; Yell, 2006; Yell \& Drasgow, 2000). The EAHCA required reauthorization by Congress every 4 or 5 years. In 1990 , when Congress reauthorized the EAHCA, it also changed the name of the law to the Individuals with Disabilities Education Act (IDEA). When Congress reauthorized IDEA in 1997 (hereafter IDEA '97), its intent seemingly was to change the focius of the law.

Although IDEA had been dramatically successful in including children with disabilities in public education, Congress believed that the promise of the law had not been fulfilled for too many children with disabilities. Congressional intent in the 1997 reauthorizations was stated most clearly in the House Committee Report:

\footnotetext{
This Committee believes that the critical issue now is to place greater emphasis on improving student performance and ensuring that children with disabilities receive a quality public education.... This reauthorization of the IDEA is needed to move to the next step of providing special educition and related services to children with disabilities: to improve and increase their educational achievement. (House Report, 1997, pp. 83-84)
}

The underlying theme of IDEA '97, therefore, was to improve the effectiveness of special education by requiring demonstrable improvements in the educational achievement of students with disabilities (Eyer, 1998; Yell, 2006). Indeed, providing a quality education that would produce real educational results for each student with disabilities had became the new goal of IDEA (Eyer, 1998; Johnson, 2003).

In IDEA '97, Congress included a number of changes in the IEP requirements to emphasize the necessity of improving educational outcomes for students with disabilities. For example, IDEA '97 required that IEPs contain measurable 
annual goals and the methods by which a student's progress toward his or her goals would be measured. In addition, IDEA '97 required that IEP teams had to regularly inform parents of students in special education of their child's progress toward his or her annual goals and the extent to which this progress is sufficient to enable the child to achieve these goals.

According to IDEA '97, the purpose of measurable annual goals is to inform the IEP team as to whether (a) the anticipated outcomes for the student are being met, and (b) the special education services and placement are effective (IDEA Regulations, 34 C.F.R., Appendix to Part 300Notice of Interpretation, question 38). Thus, IDEA '97 conveyed the clear requirement that if a student fails to make progress toward his or her annual goals, the IEP has to be revised (Clark, 1999). The reauthorized law required that the special education services that were determined in the IEP planning process must allow a student to advance appropriately toward attaining his or her annual goals.

IDEA '97 also focused on the importance of ensuring that students with disabilities would participate and progress in the general education curriculum. By requiring access to the general curriculum, Congress intended that students with disabilities would be more likely to meet "the educational standards within the jurisdiction of the public agency that apply to all children" (IDEA Regulations, $\$ 300.26$ (b) (3)(ii)). To ensure that students with disabilities would be held to the same high standards expected of all general education students, IDEA ' 97 also required that students with disabilities be included in statewide assessments or be provided with an alternative assessment. Thus, IDEA ' 97 incorporated the high expectations of state education agencies into the IEPs of students with disabilities (Johnson, 2003; Yell \& Shriner, 1997).

The 1997 amendments to IDEA seemed to clearly raise the FAPE standard to more than just a floor of opportunity (Eyer, 1998; Huefner, 2000; Johnson, 2003; Yell \& Shriner, 1997). In fact, Eyer (1998) wrote that after the reauthorization in 1997:

\begin{abstract}
the IDEA can no longer be fairly perceived as a statute which merely affords children access to education. Today, the IDEA is designed to improve the effectiveness of special education and increase the benefits afforded to children with disabilities to the extent such benefits are necessary to achieve measurable progress. (p. 16)
\end{abstract}

Similarly, when IDEA was reauthorized in 2004, congressional intent clearly was on improving instructional outcomes for students with disabilities.

\section{IDEA Amendments of 2004}

Prior to reauthorization of IDEA in 2004, President George W. Bush appointed a commission to study special education in America and to make recommendations for reauthorization. In the introduction to the final report of the President's Commission on Excellence in Special Education, A New Era: Revitalizing Special Education for Children and Their Families (President's Commission, 2001), the Commission wrote:

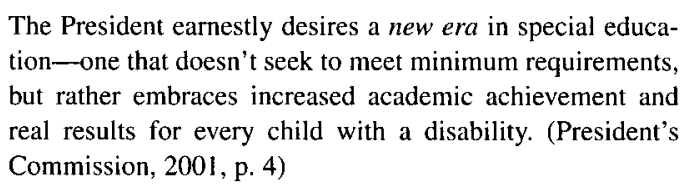

Thus, major recommendation number 1 made by the Commission was that educators must focus on results, not on process. The Commission wrote:

\begin{abstract}
IDEA must return to its educational mission: serving the needs of every child. While the law must retain the legal and procedural safeguards necessary to guarantee a "free appropriate public education" for children with disabilities, IDEA will only fulfill its intended purpose if it raises its expectations for students and becomes results-oriented-not driven by process, litigation, regulation and confrontation. In short, the system must be judged by the opportunities it provides and the outcomes achieved by each child. (President's Commission, 2001, p. 8)
\end{abstract}

Congress embraced this charge, as indicated in the following statement of findings in Part A of the Individuals with Disabilities Education Improvement Act (IDEIA):

\begin{abstract}
Improving educational results for children with disabilities is an essential element of our national policy of ensuring equality of opportunity, full participation, independent living, and economic self-sufficiency for individuals with disabilities" (IDEA, § 1401(c)(1)).
\end{abstract}

According to the findings of fact in the IDEIA, "the Federal Government [has] a supporting role in assisting State and local efforts to educate children with disabilities in order to improve results for such children" (IDEA, $\S 1401$ (c)(6)). In the regulations written to implement the IDEIA, the U.S Department of Education wrote that the purpose of the IDEA amendments of 2004 were "to assess and ensure the effectiveness of efforts to educate students with disabilities" (IDEA Regulations, $\S 300.1(\mathrm{~d})$ ).

In the IDEIA, Congress retained and expanded many of the requirements of IDEA '97, such as involvement in the general education curriculum, participation in statewide assessments, and the emphasis on developing measurable annual goals for each student in special education, monitoring each student's progress, and then reporting on this progress to his or her parents. Congress also added a few requirements, the most notable of which was the mandate that IEP teams base their programming on peer-reviewed research.

Students' IEPs now must include a statement of the special education and related services and supplementary aids 
and services, based on peer-reviewed research, to the extent practicable. Inclusion of the terminology "peer-reviewed research" is significant. When an IEP team develops a student's special education program, the services that are provided must be based on reliable evidence that the program or service works.

Although IDEIA does not define peer-reviewed research, use of this term clearly is in accordance with NCLB's requirement regarding scientifically based research (IDEA Regulations, 34 C.F.R. $\S 300.315$ et seq.). According to the language in NCLB (No Child Left Behind, 20 U.S.C. \& $1411(\mathrm{e})(2)(\mathrm{C})(\mathrm{xi}))$, scientifically based research applies the rigorous, systematic, and objective methods of science to examine and validate instructional procedures. This research (a) relies on direct observation and objective measurement (not speculation) to provide valid data; (b) controls, examines, or assesses factors to eliminate alternative explanations; (c) uses rigorous data analysis; and (d) is published in peer-reviewed journals. Further, all professional development activities and use of funds must be grounded in scientifically based research and must be directed at improving student academic achievement.

This new requirement will result in stronger and more effective programs for students with disabilities in special education. Research in recent years has enabled great advances in the areas of learning and behavior problems and effective procedures to remedy them. The President's Commission on Excellence in Special Education (2001) recommended that when IDEA was reauthorized, Congress should emphasize "aggressive intervention using research-based approaches" (President's Commission, p. 7). Further, the Commission wrote that all professional development activities for special education teachers must be grounded in scientifically based research and must focus on improving student academic achievement. It has always been good practice to know and implement research-based procedures. Now this is a requirement in the law.

The IDEIA also included a provision explicitly requiring that "a decision made by a hearing officer shall be made on substantive grounds based on a determination of whether the child received a free appropriate public education." (20 U.S.C. $\S 1415(f)(3)(E)(i))$. Procedural violations may result in denial of a FAPE only if these violations (a) impeded the child's right to a free appropriate public education, (b) significantly impeded the parents' opportunity to participate in the decision-making process regarding the provision of a free appropriate public education to a student child, or (c) caused a deprivation of educational benefits (IDEA, 20 U.S.C. $\S 1415(f)(3)(E)(i i))$. Yell, Katsiyannis, Ryan, McDuffie, and Mattocks (in press) concluded that Congress clearly intended to ensure that hearing officers examine whether the student was afforded meaningful educational benefits rather than just determining whether the school district adhered to the procedures of the law.

\section{Conclusions: FAPE, IDEA '97, and the IDEIA}

For the past 25 years, the Rowley decision has provided the framework for courts to use when determining whether students were provided with a FAPE. An analysis of the IDEA reauthorizations of 1997 and 2004, however, clearly indicates that IDEA is no longer about merely providing access to education, nor is it just about affording students a basic floor of opportunity. The law now embraces research, progress monitoring, and accountability. The law demands improved results for students with disabilities. Clearly, this will require changes in the ways that school-based teams develop IEPs, and this, in turn, should influence courts on how they view and assess FAPE (Johnson, 2003).

An examination of the post-Rowley decisions indicates that many courts, while moving beyond the "some educational benefit" standard to a "meaningful education benefit" standard, still rely on the Rowley standard for guidance when determining if a student has received a FAPE. On one hand, this is understandable because the U.S. Supreme Court is the highest court in the land, lower courts follow the authority of the high court, and for 25 years Rowley has provided the structure for deciding FAPE cases. On the other hand, the puzzling aspect of this reliance shown by some lower courts is that the "some educational benefit" standard no longer accurately reflects the changes Congress made to IDEA in the reauthorizations of 1997 and 2004, and because of these changes, lower courts can go beyond Rowley in interpreting the FAPE mandate.

The changes in IDEA will eventually result in a fundamental alteration in the ways in which the courts view a FAPE. The language in the first section of IDEA, titled "Findings," maintains that "the implementation of (IDEA) has been impeded by low expectations, and an insufficient focus on applying replicable research on proven methods of teaching and learning for children with disabilities" (IDEA $\S 1400(\mathrm{c})(4))$, and that:

almost 30. years of research and experience has demonstrated that the education of children with disabilities can be made more effective by-

(A) having high expectations for such children and ensuring their access to the general education curriculum in the regular classroom, to the maximum extent possible, in order to-

(i) meet developmental goals and, to the maximum extent possible, the challenging expectations that have been established for all children; and

(ii) be prepared to lead productive and independent adult lives, to the maximum extent possible. (IDEA $\$ 1400$ (c)(5))

Clearly, the plain meaning of the law is no longer about simply providing access, a basic floor of opportunity, and 
some educational benefit. In 25 years, the times and the definition of FAPE have changed. A quarter century ago, the Rowley standard reflected the intent of Congress in fashioning the EAHCA; however, it no longer does. Given the knowledge we have accumulated in 25 years of research on educating students with disabilities, providing services that merely offer some educational benefit is no longer acceptable.

What will it take for the courts to go beyond Rowley and embrace the definition of FAPE in the new IDEA? Two important points that we must acknowledge are that

1. courts don't make the law; the courts interpret the law, and

2. the U.S. Supreme Court will not voluntarily answer questions unless they are directly asked.

Thus, a direct challenge to the Rowley standard may be required, in which a court, or the Supreme Court, is asked to reinterpret FAPE given the plain meaning of the new IDEA.

\section{RECOMMENDATIONS FOR SPECIAL EDUCATORS, ADMINISTRATORS, AND TEACHER TRAINERS}

IDEA now requires that special educator programs confer meaningful educational benefit, and that these programs are grounded in research-based practices. Yell, Shriner, and Katsiyannis (2006) proposed five guidelines to help ensure that special education programs meet the requirements of the IDEIA. We offer these suggestions for special education teachers and administrators to follow in developing educational programs that meet the requirements of IDEA and confer meaningful educational benefit to the students with whom they work.

\section{Recommendation \#1: Ensure that teachers and adminis- trators understand the essence of a FAPE in accordance with IDEA'97 and the IDEIA.}

IDEA is a complex law, and special educators, administrators, and teacher trainers have to understand the requirement that special education programs meet the FAPE requirements. To ensure that public schools fulfill these obligations, special educators must

1. conduct relevant assessments of students that provide information to teachers on a student's unique academic and functional needs and how best to address those needs;

2. develop meaningful educational programs for students based on the assessment, which consists of special education and related services grounded in research-based practices;

3. generate measurable annual goals that will be used to monitor a student's academic and functional progress; and
4. monitor the student's progress by collecting data on his or her growth toward those goals, and make instructional changes when necessary.

IDEIA emphasizes the importance of meaningful programming by stressing the importance of the outcomes of a student's education.

\section{Recommendation \#2: Ensure that special education teachers understand and use research-based procedures.}

The importance of using research-based educational procedures is stressed in both NCLB and IDEIA. Because of the IDEA requirement that special education programs deliver meaningful benefit, this level of benefit likely will not be realized when ineffective instructional strategies are used. Thus, teachers must understand and properly implement educational practices based on the latest research. Quite simply, special education programming must produce meaningful educational benefit, and the way that administrators and teachers can ensure this is to use educational procedures that show evidence of producing meaningful outcomes. In addition to understanding and being able to implement research-based practices, special educators will need in-depth knowledge of available resources and be able to distinguish legitimate research from fads and educational procedures lacking an evidence base.

\section{Recommendation \#3: Ensure that special education teachers know how to collect and use formative data to monitor student progress.}

IDEIA increases the federal mandate that requires teachers to monitor student progress. It accomplishes this in four major ways (Yell, Shriner, \& Katsiyannis, 2006):

1. The law requires that IEP team members develop 'measurable annual goals in students' IEPs.

2. The IEP must delineate how these goals will be measured. That is, special education teachers must use a progress monitoring system.

3. Special education teachers must monitor a student's progress toward meeting these annual goals at least every 9 weeks and report the student's progress to his or her parents.

4. Teachers must make instructional changes when a student's progress is not sufficient to achieve his or her goals.

Thus, the law requires that a student's IEP includes annual goals that can be measured, and that teachers actually measure progress toward these goals. Moreover, instructional changes must be made when the data indicate that a student is not progressing. 
As discussed previously, IDEA now requires that special educators develop and deliver individualized special education programs that confer meaningful education benefits to students in special education. To ensure that special education programs confer meaningful benefit and, thus, meet requirements of IDEA, special education teachers must be able to collect data to determine if their instructional and behavioral programs are working and that their students are making progress toward meeting their measurable annual goals.

By using such data, teachers' educational decisions will be guided by objective data. If the data show that a student is not learning, the teacher can make instructional changes and continue to collect data to determine if the instructional changes are working. Teachers can adjust their instruction in response to student performance (Yell \& Stecker, 2003), thereby ensuring that the educational programs confer meaningful educational benefit.

\section{Recommendation \#4: Ensure that special education teachers understand how to develop educationally mean- ingful and legally sound IEPs.}

To ensure that IEPs are educationally meaningful and legally correct, special educators must (a) conduct assessments that address a student's instructional needs, (b) develop meaningful special education using research-based strategies and procedures, (c) collect data to monitor student progress and plan and adjust instruction based on the data, and (d) report the student's progress to his or her parents (Yell, Shriner, \& Katsiyannis, 2006). Individualized education programs that are based on inadequate assessments, contain goals that are not individualized or appropriate, and have no progress-monitoring component most likely will not provide educational benefit.

\section{Recommendation \#5: Ensure that special education teachers receive meaningful and sustained inservice training programs to train them in new research-based practices and other developments in special education.}

Of paramount importance, administrators must ensure that special education teachers have the necessary skills and tools to implement evidence-based practices. There is a huge gap between (a) what we know works from scientifically based research and (b) what actually is taught in many classrooms (Yell \& Drasgow, 2005). This means that teacher trainers and school district administrators will have to structure preservice and inservice training activities to ensure that teachers become fluent in research-based practices. In addition, they should know how to access research through peerreviewed literature. Administrators must develop mechanisms to ensure that teachers receive regular and frequent inservice training experiences in the latest peer-reviewed research. Moreover, when an administrator evaluates a teacher, the administrator should assess the extent to which the teacher uses research-based practices.

\section{SUMMARY}

June 29, 2007, was the 25th anniversary of the U.S. Supreme Court's decision in Board of Education of the Hendrick Hudson Central School District v. Rowley. This was the first opportunity for the high court to interpret the FAPE requirement of the EAHCA. The Supreme Court held that FAPE was a right of all students in special education. Writing for the majority, Justice Rehnquist stated that a FAPE consists of educational instruction designed to meet the unique needs of a student with disabilities, supported by services as needed to permit the student to benefit from instruction. The court noted that IDEA requires that these educational services be provided at public expense, meet state standards, and comport with the student's IEP. If individualized instruction allows the child to benefit from educational services and is provided in conformity with the other requirements of the law, the student is receiving a FAPE.

The Supreme Court also ruled that students with disabilities do not have an enforceable right to the best possible education or an education that allows them to achieve their maximum potential. Rather, they are entitled to an education that is reasonably calculated to confer some educational benefit.

In addition, the Supreme Court developed a two-part test to be used by courts in determining if a school has met its obligations under IDEA to provide a FAPE:

\footnotetext{
First, has the [school] complied with the procedures of the Act? And second, is the individualized education program developed through the Act's procedures reasonably calculated to enable the child to receive educational benefits? (pp. 206-207)
}

Court decisions immediately following the Rowley decision tended to apply the high court's ruling in a strict manner. That is, they applied the Rowley test by first examining the IEP and the procedural history of the case to determine whether the first part of the test had been satisfied. Second, the courts examined the student's IEP to determine whether the IEP would confer some educational benefit. Often, if a court found that the first part of the Rowley test was met and the school district was able to show some educational benefit, no matter how minimal, the court upheld the school's provision of a FAPE. Faced with difficult FAPE decisions, however, some courts began to rule that the law's FAPE requirement meant more than simple access to education. These courts ruled that a FAPE must confer meaningful educational benefit on the student. An education conferring minimal or trivial progress was insufficient. 


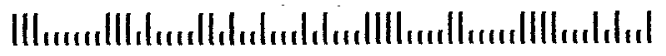

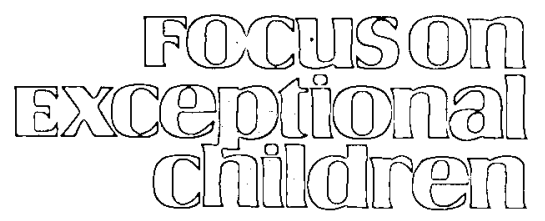

In the 25 years since the Rowley decision, the major purpose of IDEA has shifted from providing access to educational services to providing meaningful and measurable programs for students with disabilities. We believe that schools and programs are now going to be held to a higher standard in providing educational services for students with disabilities. Educators must be prepared to meet this challenge. These changes will eventually require the courts to reexamine the Rowley ruling and the "some educational benefit" standard. We hope the challenge comes sooner rather than later.

\section{Authors' Note}

After losing the case in the Supreme Court, the Rowley family moved from New York to New Jersey. Amy attended a school that served a number of deaf children and had ASL interpreters available in classrooms. She performed extremely well during the rest of her school career. Amy is currently coordinator of the American Sign Language Program in the Department of Exceptional Education, University of Wisconsin-Milwaukee, and is working on her $\mathrm{PhD}$. She is married to Jeff Mosher, and they have three children. Her two daughters, Janeva and Resa, are deaf and attend the Milwaukee sign language school, which is attended by both deaf and hearing children. Amy is still involved in working to ensure that all children with disabilities have access to an appropriate—and meaningful-education.

\section{REFERENCES}

Amy Rowley v. Hendrick Hudson Central School District, 483 F. Supp. 528 (1979).

Battle v. Commonwealth of Pennsylvania, 628 F.2d 269 (3rd Cir. 1980).

Board of Education of East Windsor Regional School District v. Diamond, 808 F.2d 987 (3d Cir. 1986).

Board of Education of the Hendrick Hudson School District v. Rowley, 458 U.S. 176 (1982).

Burlington School Committee v. Massachusetts Department of Education, 471 U.S. 359 (1985).

Carter v. Florence County School District Four, 950 F.2d 156 (4th Cir. 1991).

Chris C. v. Gwinnett County School District, 780 F. Supp. 804 (N.D. Ga. 1991).

Clark, S. G. (1999). Assessing IEPs for IDEA compliance. Education Law Reporter, 137, 35-42.

Cypress-Fairbanks Independent School District v. Michael F, 118 F.3d 245 (5th Cir. 1997).

Doe v. Smith, EHLR 559: 391 (N.D. Tenn. 1988).

Eyer, T. L. (1998). Greater expectations: How the 1997 IDEA amendments raise the basic floor of opportunity for children with disabilities. Education Law Reporter, 126, 1-19.

Hall v. Vance County Board of Education, 774 F.2d 629 (4th Cir. 1985).

House of Representatives Report on P.L. 105-17 (1997), available at wais.access.gpo.gov
Houston Independent School District v. Bobby R., 200 F.3d 342 (5th Cir. 2000).

Huefner, D. S. (2000). Getting comfortable with special education law: A framework for working with children with disabilities. Norwood, MA: Christopher-Gordon.

Individuals with Disabilities Education Act, 20 U.S.C. \$ 1400 et seq.

Individuals with Disabilities Education Act Regulations, 34 C.F.R. § 300.533 et seq.

J. C. v. Regional School District, 23 IDELR 1181 (3rd Cir. 1996).

Johnson, S. F. (2003). Reexamining Rowley: A new focus in special education law. The Beacon: Journal of Special Education Law \& Practice, 2(2), 1-20. Downloaded 3/11/07 from http://www.harborhouselaw. com/articles/rowley.reexamine.johnson.htm

Katsiyannis, A., Yell, M. L., \& Bradley, R., (2001). Reflections on the 25th anniversary of the Individuals with Disabilities Education Act. Remedial and Special Education, 22, 324-334.

Lascari v. Board of Education, 116 N.J. 30 (1989).

Nein v. Greater Clark County School Corporation, 95 F. Supp. 2d 961 (S.D. Ind. 1999).

Osborne, A. G., \& Russo, C. J. (2006). Special education and the law: A guide for practitioners. Thousand Oaks, CA: Corwin Press.

Pace v. Bogalusa City School Board. 325 F.3d 609 (5th Cir. 2003).

Polk v. Central Susquehanna Intermediate Unit 16, No. 16, 853 F.2d 171 (3rd Cir. 1988).

President's Commission on Excellence in Special Education. (2001). A new era: Revitalizing special education for children and their families. Retrieved July 24, 2001, from http://www.ed.gov/inits/commissions boards/whspecialeducation/reports/images/Pres_Rep.pdf

Ridgewood Board of Education v. N. E., 172.F.3d 238 (3rd Cir. 1999).

Roland M. v. Concord School Committee, 910 F.2d 983 (1st Cir. 1990).

Ross v. Framington School Committee, 44 F. Supp. 2d 104 (D. Mass. 1999).

Smith, R. C. (1996). A case about Amy. Philadelphia: Temple University Press.

Timothy W. v. Rochester School District, 875 F.2d 954 (1st Cir. 1989).

Wenkart, R. D. (2000). Appropriate education for students with disabilities: How courts determine compliance with the IDEA. Horsham, PA: LRP.

Yell, M. L. (2006). The law and special education (2nd ed.). Upper Saddle River, NJ: Merrill/Prentice Hall.

Yell, M. L., \& Drasgow, E. (2005). No Child Left Behind. Upper Saddle River, NJ: Pearson/Merrill/Prentice Hall.

Yell, M. L., Drasgow, E., Bradley, R., \& Justesen, T. (2004). Critical legal issues in special education. In A. McCray Sorrells, H. J. Reith, \& P. T. Sindelar, Issues in special education (pp. 16-37). Boston: Allyn and Bacon.

Yell, M. L., Katsiyannis, A., Ryan, J. B., McDuffie, K. \& Mattucks, L. (In press). Twenty ways to ensure compliance with the Individuals with Disabilities Education Improvement Act of 2004. Intervention in School and Clinic.

Yell, M. L., \& Shriner, J. G. (1997). The IDEA Amendments of 1997: Implications for special and general educators, administrators, and teacher trainers. Focus on Exceptional Children, 30, 1-19.

Yell, M. L., Shriner, J. G., \& Katsiyannis, A. (2006). The Individual with Disabilities Education Improvement Act of 2004: Implications for special and general educators, administrators, and teacher trainers. Focus on Exceptional Children 39(1), 1-24.

Yell, M. L., \& Stecker, P. M. (2003). Developing legally correct and educationally meaningful IEPs using curriculum-based measurement. Assessment for Effective Intervention, 28, 73-88. 
Copyright of Focus on Exceptional Children is the property of Love Publishing Company and its content may not be copied or emailed to multiple sites or posted to a listserv without the copyright holder's express written permission. However, users may print, download, or email articles for individual use. 